\title{
Corrigendum: Antimicrobial activity of mucosal-associated invariant T cells
}

Lionel Le Bourhis, Emmanuel Martin, Isabelle Péguillet, Amélie Guihot, Nathalie Froux, Maxime Coré, Eva Lévy, Mathilde Dusseaux, Vanina Meyssonnier, Virginie Premel, Charlotte Ngo, Béatrice Riteau, Livine Duban, Delphine Robert, Martin Rottman, Claire Soudais \& Olivier Lantz

Nat. Immunol. 11, 701-708 (2010); published online 27 June 2010; corrected after print 13 August 2010

In the version of this article initially published, the author Shouxiong Huang (Department of Pathology and Immunology, Washington University, St. Louis, Missouri, USA) was not included. This author should be listed as author 15 (and affiliation 8). The error has been corrected in the HTML and PDF versions of the article.

\section{Corrigendum: Activation of innate immune antiviral responses by Nod2}

Ahmed Sabbah, Te Hung Chang, Rosalinda Harnack, Victoria Frohlich, Kaoru Tominaga, Peter H Dube, Yan Xiang \& Santanu Bose Nat. Immunol. 10, 1073-1080; published online 23 August 2009; corrected after print 25 June 2010

In the version of this article initially published, some panels in Figure 8e were incorrect. The error has been corrected in the HTML and PDF versions of the article.

\section{Erratum: Understanding immunity requires more than immunology}

\section{Kevin J Tracey}

Nat. Immunol. 11, 561-564 (2010); published online 18 June 2010; corrected after print 25 June 2010

In the version of this article initially published, the affiliation provided was incorrect. It should read as follows: "Kevin J. Tracey is with the Center for Biomedical Science, Feinstein Institute for Medical Research, Manhasset, New York, USA." The error has been corrected in the HTML and PDF versions of the article.

\section{Erratum: Deletion of the RNA-binding proteins ZFP36L1 and ZFP36L2 leads to perturbed thymic development and T Iymphoblastic leukemia}

Daniel J Hodson, Michelle L Janas, Alison Galloway, Sarah E Bell, Simon Andrews, Cheuk M Li, Richard Pannell, Christian W Siebel, H Robson MacDonald, Kim De Keersmaecker, Adolfo A Ferrando, Gerald Grutz \& Martin Turner Nat. Immunol. 11, 717-724 (2010); published online 11 July 2010; corrected after print 22 July 2010

In the version of this article initially published, two labels in the key in Figure 1a are reversed. The correct labels are dKO (red line) and Control (blue line). The error has been corrected in the HTML and PDF versions of the article. 